\title{
Monitoring of Tirana River and the Margin of Data in Urbanized and Non Rezidental Area
}

\author{
Julis Selamaj $^{1}$, Milidin Bakalli ${ }^{*}$, Margarita Hysko \\ ${ }^{1}$ Microbiologycal Laboratory, Central Laboratory of Armed Forces, Albania \\ 2 Department of Medicine, Faculty of Professional Study, University "Aleksander Moisiu”, Durrës, Albania \\ ${ }^{3}$ Department of Biology, Faculty of Natural Science, University of Tirana, Albania
}

*Corresponding author: bakallim@gmail.com

\section{ABSTRACT}

Tirana River is one of the main branches of Ishmi river and serves as collector for wastewater discharge, for the capital city and its surrounding rural areas. This river created the north administrative border of Tirana and it's formed from mountainouse conflux in Zall-Dajt area. Besides increasing the amount of sewage discharge into the river, as a result of population growth, it is a fact that in Tirana river solid waste from non-responsible businesses and different urban wastes are being deposited. The purpose of this study is to assess the microbiological quality of Tirana river by collecting reliable information about conditions in different area wherever the river course outside and inside the Tirana city. Samples were taken at four different points during year 2012-2013. The river is tested for indicators of pollution such as Streptoccocus faecali and Escherichia coli as well as the presence of actinomycetes. Microbiological contamination tests show relatively large water contamination, especially in three areas where the river passes in residential area. Bacteria are transported to the River via storm water, catch basins, sediment, runoff, discharges, and spills. Larger amounts of bacteria reach the river when surrounding lands are more highly developed or "urbanized." The high level presence of these microorganisms indicates that the water quality of the river is very bad according to standards, presenting a risk to health of all the organisms that inhabit the sweet waters. River areas in considerable distance from residential areas, show microbiological level lower than in those close to residential areas. It is noticed also, a growth of temperature and TDS. This growth was more evident during raining days for TDS and temperature during drought periods of monitoring.

Key words: Tirana river, Contaminate, Bacteria, Growth, Conductivity, TDS

\section{INTRODUCTION}

Tirana River served as collectors sewage discharge of the capital city and the surrounding rural areas for a period of over 50 years. Today, as well as the increasing amount of sewage discharge into the river, always due to the population growth of the city, we observed a new phenomenon: that Tirana river serves as the area of solid waste discharge. Along the entering course in the city area near Bridge of Brari up to Kamza curves, it is noted that on both sides of the banks there are found many urban solid waste and solid waste from various businesses that operate near the river flow. Tirana river valley retains the characteristics of mountain. The main source of pollution of natural waters are wastewater discharges. In regions with low population density, the water pollution problems are not visible because of the ability of self cleaning characteristic of water. But with increasing urbanization rate, water selfcleaning ability fails to withstand discharges of untreated sewage and consequently damaging effects observed in water biot, risk of infection, etc. From 
various studies shows that in our country in the past two decades the main source of surface water pollution are urban discharges. As urban sewage waters and other industrial emissions discharge directly into receiving waters without being crude and then pass on these rivers bringing their pollution. In urban areas with high population, the problem of surface water pollution is more sharp. Sewerage system in Tirana city is a combined system, which includes urban water used, industry related with the network as torrential waters discharged from the surfaces of streets, squares and all impervious surfaces. All sewage is free flowing and its dismissal is at the bottom of the river and the river Lana Tirana. Tirana river segment from the source to the bridge of Brari represents the upper flow of the river of Tirana, which brings clean water to mountain areas contaminated by human activity. Area water from the bridge of Brari down to Kamza Bridge, serves as collector for water discharge of untreated urban part of the city sewerage network in Tirana and numerous commercial activities and industrial Bode (2012). In Tirana river discharge collector road "Siri Kodra " which summarizes the network upstream of the city, the collector road "Bajram Curri" as a part of the ring. On the left side of river discharges collector road "5 Maji", which in addition to the upper zone encompasses residential and collector of former industrial area.

\section{MATERIALS AND METHODS}

Water is extremely portable and is characterized by a great homogeneity. The main forms of occurrence of chemical elements in it, is chemically dissolved and colloidal Merck (1982). Samples were taken for analysis to represent the characteristics of the water system is under study, while those not taken near the shore of the river but in the river where the water was rapidly flow.

\section{Testing area and monitoring stations}

In this study, are presented data of 72 samplea of water taken from June 2012 to June 2013. The monitored areas in Tirana River are: T1. Brari Bridge (Figure 1) is located in the northern part of the city and the river segment before entering the city. From an environmental perspective it represents a non-polluted area (pre pollution). River waters are generally clear. The river here is rocky coastlines (limestone) steep. The waters are under the influence of emissions of Brari village and their agricultural lands. In the Mediterranean broadleaf shrubs slopes there. Bed width reaches up to $50 \mathrm{~m}$ and $30 \mathrm{~cm}$ depth, the water is lit. Bed mainly contains large stones over $40 \mathrm{~cm}$ and medium 20-40 cm,it is poor in gravel, sand and organic matter. T2. (Figure 2), $.500 \mathrm{~m}$ from the collector area at "Siri Kodra" belongs to a polluted area as a result of the discharge of urban sewage collector of the city of Tirana. The site chosen for the taking of the sample corresponds to a distance of about $500 \mathrm{~m}$ from the main collector. T3. (Figure 3), the turn around area to Kamëz Bridge. This area represents the third station River flow of Tirana, after passing through the area inhabited (peripheral). The station is located at a distance of 200-400 $\mathrm{m}$ from the bridge The waters here are under the influence of urban discharges a good portion of the capital city and many companies or industrial workshops (Figure 4), settled along the craft river banks on both sides. Also, the land along the river is sown. The bed of the river reaches up to $15 \mathrm{~m}$ and depth about $30 \mathrm{~cm}$. Water flow and velocity undergo significant fluctuations seasonal. In suburban areas on the banks of the Tirana river and Lana River serve as collector of discharge solid waste. They are filled with inert waste and urban 
waste which significantly increase the levels of pollution of their waters Bode (2012).

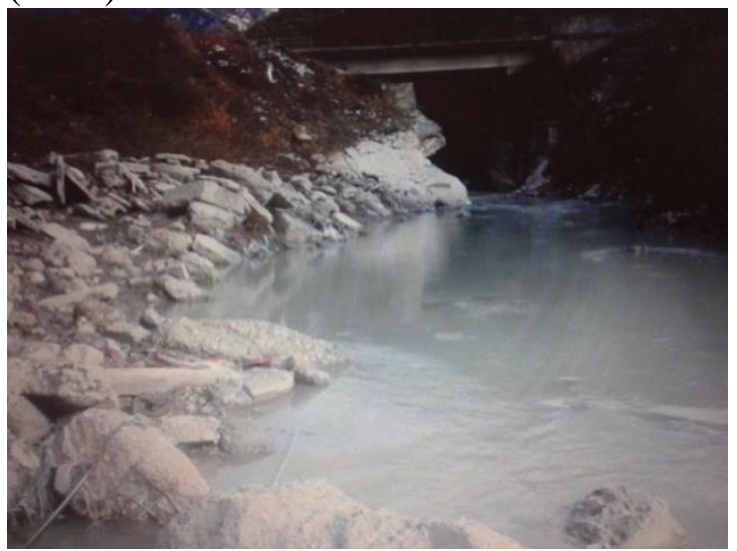

Figure 1: T1 zone (Photos J. Selamaj, M. Bakalli)

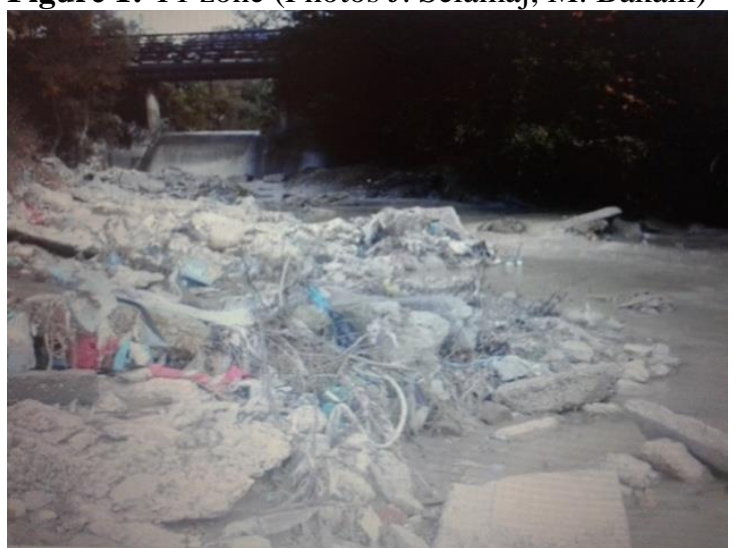

Figure 2: T2 zone (Photos M. Bakalli)

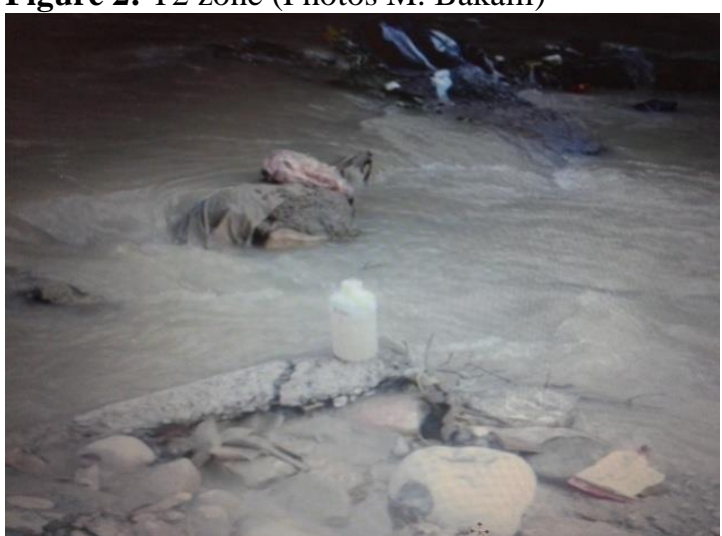

Figure 3: T3 zone (Photos J. Selamaj, M. Bakalli)

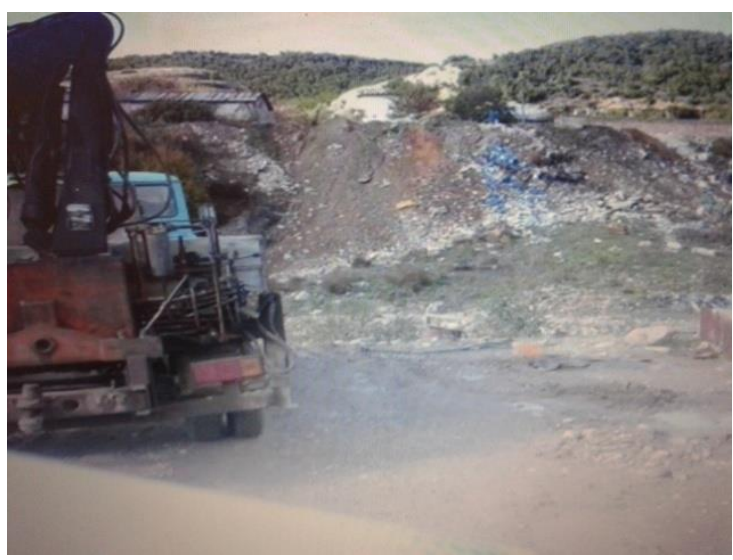

Figure 4: Industrial activity (Photos J. Selamaj)

For selecting sampling scheme references were taken from sources of pollution at a distance of 500 meters. To see the impact of urban discharges into the river, sampling was conducted in two types of aquatic areas with significant changes in the level of contamination Corbitt (1999). Area of contaminated water from anthropogenic activity, corresponding to the flow of the river before entering the city. Waterfront area affected by discharges of urban and industrial waste water of the Tirana city to match the area as the river has overwhelmed the city, then flow downstream. Samples are tested for physicochemicals parameters: odor by smeling, color by visual inspection, temeperature, TDS, $\mathrm{pH}$ and conductivity, and microbiologycal indicator Escherichia coli, Streptoccocus faecalis which are based ISO 7899-1 are given in table 1. Measurement of $\mathrm{pH}$, temperature, conductivity and TDS are performed with precision directly from us at the time of sampling by $\mathrm{MM} 40^{+}$. All reagents for chemical and microbiological analysis AR reagents used were obtained from various manufacturers such as Sigma Aldrich, Himedia, and Sifin. The amount of sample taken for analysis is 0.5 liter. Sample bottles are sterilized in the autoclave for 20 minutes at a temperature of $120{ }^{0} \mathrm{C}$ Borrell Fontelles \& Winkler (2006). 
Table 1. Microbial standards (ISO 7899-1) for fecal and total coliforms of water quality in rivers and stream

\begin{tabular}{|c|c|c|c|c|}
\hline \multirow[t]{2}{*}{ Microbiology } & \multicolumn{4}{|c|}{ EU standard ISO 7899-1 } \\
\hline & Very good & Good & Bad & Very bad \\
\hline Fecal coliforms,CFU/100 ml & $250-500$ & $500-1000$ & $1000-2000$ & Over 2000 \\
\hline Total coliforms,CFU/100 ml & 1250 & 2500 & 5000 & 10000 \\
\hline $\begin{array}{l}\text { ansport and storage of sam } \\
\text { testing was done with box } \\
\text { nperature } 4-7{ }^{0} \mathrm{C} \text {. Samples a } \\
\text { the same day Figueras }\end{array}$ & & \multicolumn{3}{|c|}{$\begin{array}{l}\text { Streptomyces lavendulae, and inhibitec } \\
\text { Escherichia coli }(\mathrm{M} 490) \text {. Results are } \\
\text { expressed CFU/100 } \mathrm{ml} \text { Hysko }(2007) \text { for } \\
\text { indicator of pollution and CFU/ml for } \\
\text { actinomycetes. }\end{array}$} \\
\hline
\end{tabular}

(2000). Escherichia coli and Streptococcus faecalis are determination by the multiple fermentation tubes MPN (EPA, 1986). For the determination of Escherichia coli are used Lactose peptone broth media. Incubation at $36{ }^{\circ} \mathrm{C}$ $\pm 1{ }^{\circ} \mathrm{C}$ for 48 hours. Noticed the presence of tubes where the gas bubbles we have blown indole, a color change indicates the presence of Escherichia coli. Determination of Streptococcus faecalis are been by using Bromocresol-purple Azide broth. Incubation was at $36{ }^{\circ} \mathrm{C} \pm 1$ ${ }^{\circ} \mathrm{C}$ for 48 hours. Change the color of yellow field indicates the presence of Streptococcus faecalis. For the presence and identification of actinomycetes was used Aktinomycete Isolation Agar Media, which used for isolation and propagation of Actinomycetes from soil and water. Method used is covered planting. Dishes petri are incubating at temperature 35-37 ${ }^{\circ} \mathrm{C}$ for 40-72 hours. The existence of luxuriant colonies indicates the presence of actinomycetes. In this media grow these species, Nocardia asteroides, Streptomyces slbus subsp albus and

\section{RESULTS AND DISCUSSION}

Odor, and color. The observation showed that Tirana River water T2 and T3 station are bad colored and odor. pH. The $\mathrm{pH}$ values of water samples varied between 7.2 to 7.6 and were found within the limit prescribe by Bratli 2000

Temperature. Temperature is an important biologically significant factor, which plays an important role in the metabolic activities of the organism. The temperature was ranging from $8{ }^{\circ} \mathrm{C}$ to 19 ${ }^{0} \mathrm{C}$ during the study period.

Conductivity $\mu \mathrm{S} / \mathrm{cm}$ : Conductivity is a measure of ionic content in a solution Gray (2004) In many case, conductivity is linked directly to the total dissolved solids. Conductivity values of water samples were in the range $1330 \mu \mathrm{S} / \mathrm{cm}$ to $1998 \mu \mathrm{S} / \mathrm{cm}$.

Total Dissolved Solids (TDS) in $\mathrm{mg} / \mathrm{l}$ : Total dissolved solids indicate the salinity behavior of groundwater. TDS values varied from $840 \mathrm{mg} / \mathrm{L}$ to $1230 \mathrm{mg} / \mathrm{L}$. 
Table 2. Results of the physico-chemical parameters

\begin{tabular}{lllllll}
\hline & \multicolumn{3}{c}{ Wet season } & \multicolumn{3}{c}{ Dry season } \\
Physico-chemical & T1 & T2 & T3 & T1 & T2 & T3 \\
parameters & station & station & station & station & station & station \\
\cline { 2 - 7 } TDS & 840 & 890 & 890 & 941 & 1000 & 1230 \\
pH & 7.2 & 7.5 & 7.6 & 7.2 & 7.2 & 7.4 \\
Conducivity & 1330 & 1349 & 1372 & 1337 & 1358 & 1360 \\
Temperature & 8 & 8.5 & 9 & 14 & 15 & 19 \\
\hline
\end{tabular}

From the microbial data reported in the Figure 5 to 6 , if compare with EU Standard ISO 7899-1 (Tab. 1) the situation of Tirana river seems extremely bad. The presence of both E. coli and/or faecal coliforms in aquatic environments has been described as an indication of sewage or faecal contamination as they are commonly isolated from the intestinal tract of warm-blood animals. Currently, E. coli is considered to be the most specific indicator of faecal contamination PADW (2010). From the microbiological data reported (Table 1), the situation of the river seems extremely bad, as suspected; the values of $E$. coli and $S$. fecalis are several fold higher even for the respective guide values for very bad waters.
It is noticed a statistical difference between the findings obtained in areas outside the urban area of the city of Tirana and over-crowded urban area, regardless this difference. Also noticed the presence of aktinomycetes Figure 7. Actinomycetes have a global distribution especially in the upper soil layers (Mariet, 1963; Schaal \& Bickenbach 1978). There is a difference between drain and weet season for the presence of microbiologycal contamination. Where flows have been greater there is a small difference in pollution for non-urban and urban areas. Anywa, in all cases, nonurban areas show very high contamination. We think that a reason for

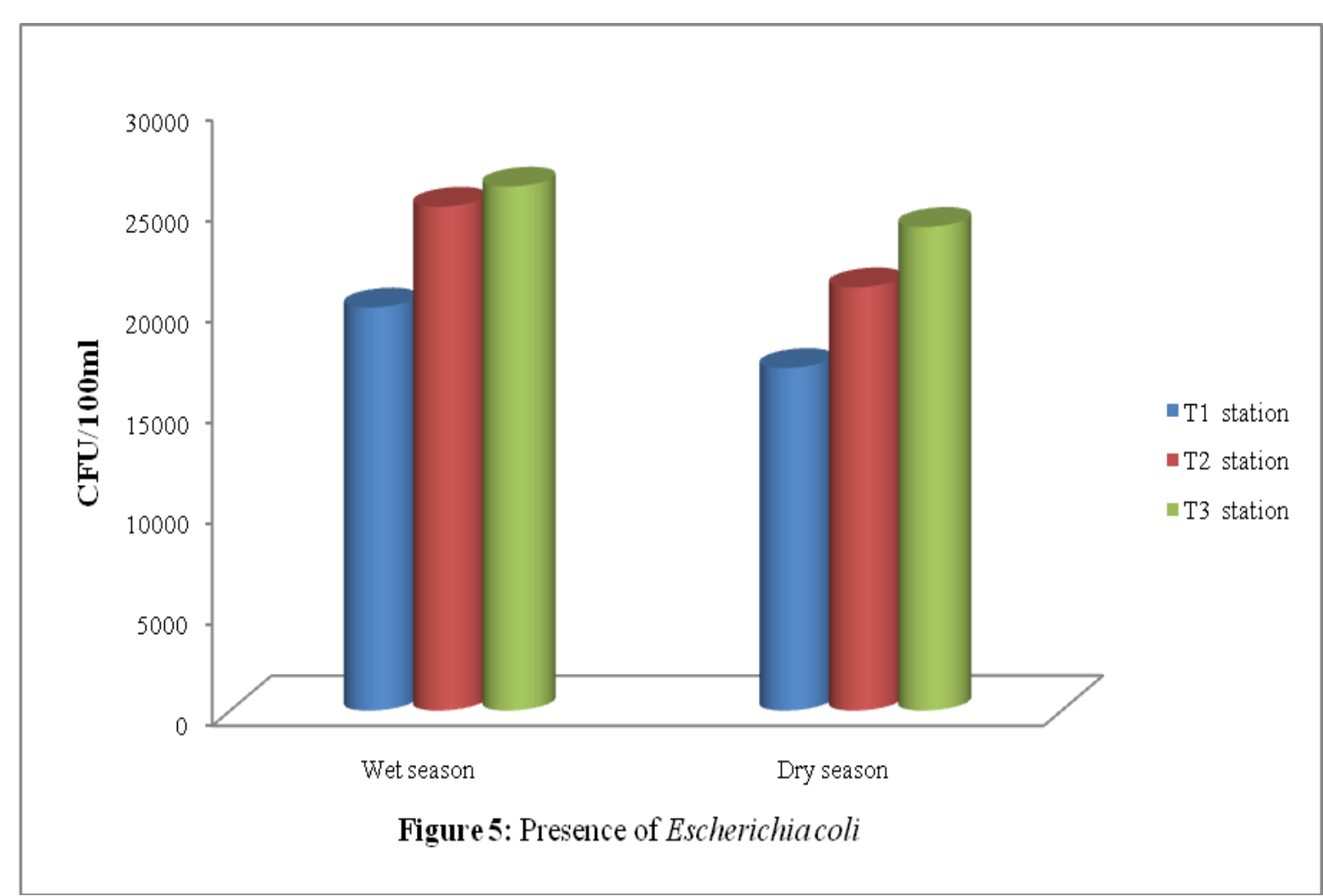



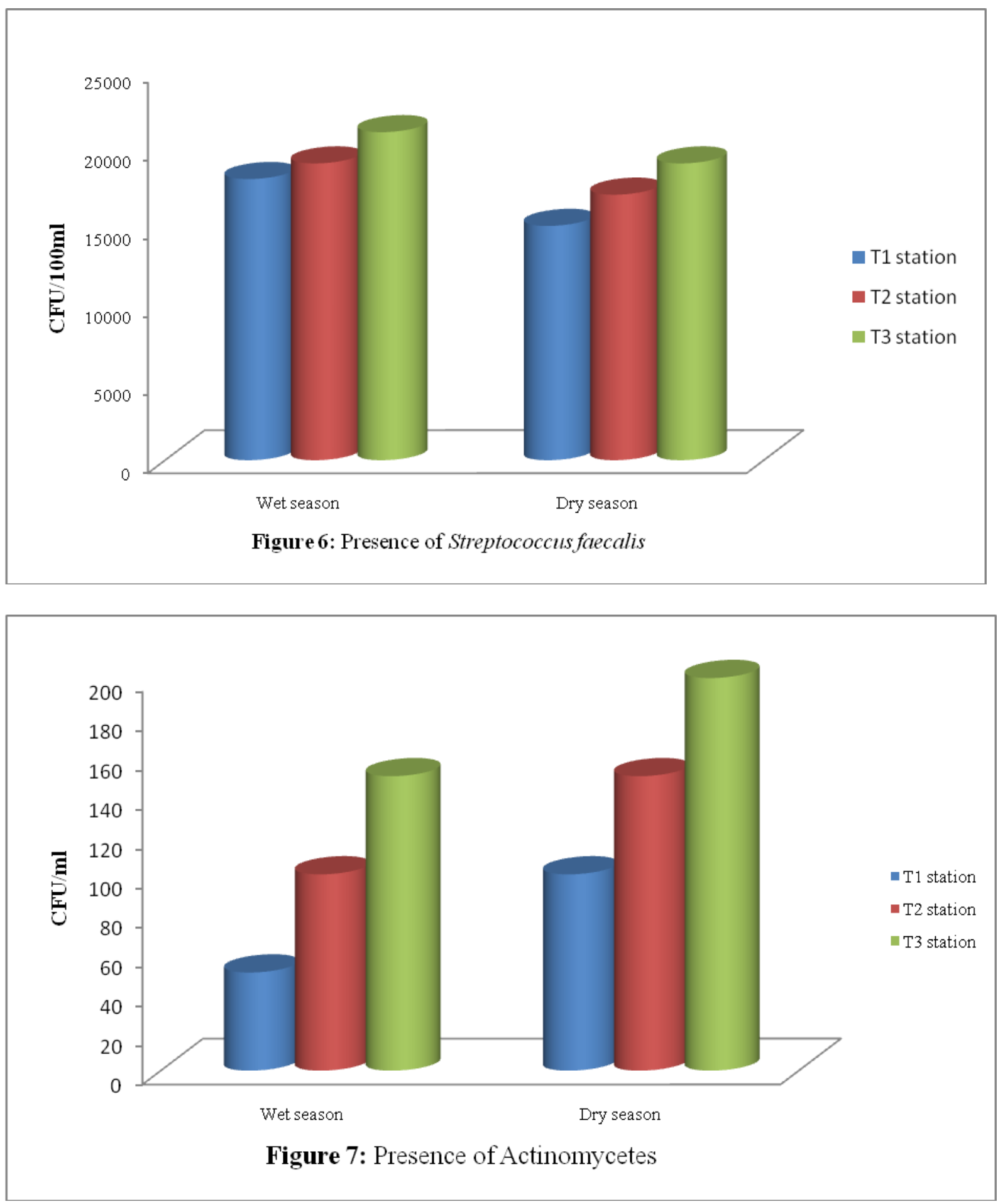

this pollution are the inert companies found in the use of the river banks, leaving all their activities emit negative impact on the surrounding areas, removal of solid waste on the banks of the river and the increased territories used for housing has led to increased rural areas and increase the their activity which affects Tirana river. At the time this occurred, the source water may have been contaminated by pathogens or disease

producing bacteria or viruses which can also exist in fecal material. Some waterborne pathogenic diseases include typhoid fever, viral and bacterial gastroenteritis and hepatitis A. The presence of fecal contamination is an indicator that a potential health risk exists 
for individuals exposed to this water. Fecal coli form bacteria may occur in ambient water as a result of the overflow of domestic sewage or nonpoint sources of human and animal waste Miho et al. (2010).

\section{CONCLUSION}

From the results, we may confirm that the water of Tirana river is very polution by presence of several parameters, from TDS, Conductivity to the microbial data. If compare with EU standard ISO 7899-1 this water characterized very bad. This water is very harmful for the biota and the people that live near the bank. It is difficult to pinpoint any one particular source of bacterial contamination in Tirana river since bacteria enter streams from a number of sources including: Storm water runoff (may contain multiple sources of bacteria, wastewater treatment plant discharges, wastewater overflows or inadequate treatment technology, sewer line leaks, tras failing septic systems, wildlife birds - waterfowl in particular, pet waste, human waste, farm animal. Larger amounts of bacteria reach the river when surrounding lands are more highly developed or "urbanized." .Through ongoing monitoring efforts we hope to better understand the cause of elevated bacteria levels especially during and following rain events, and work toward reducing or keeping bacteria from entering the Tirana river.

\section{ACKNOWLEDGEMENTS}

The paper was supported by the authors.

\section{REFERENCES}

Bode, A. 2012. Impakti ambiental i fakëtorëve antropogjene në pellgun e ujëmbajtësit të Tiranës. Accession at. http://www.dibmin-

fgjm.org.DisertacioniABode.
Borrell Fontelles \& Winkler, 2006. DIRECTIVE 2006/7EC of European Parliament andd the Council of 15 February 2006: Concerning the Management of Bathing Water Quality and Repealing Directive 76/160/EEC. Official Journal of European Union, $\mathrm{nr}$ 64:35-51.

EPA, 1986. Method 9131, Total Coli form: Multiple Tube Fermentation technique.

FIGUERAS, M. J., BORREGO, J. J. 2000. "Sanitary Inspection and Microbiological Water Quality" Selected from the Book "Monitoring Bathing Water". A Practical Guide to the Desing and Implementation of Assessment and Monitoring programmers, pp 22-84.

GRAY, JAMES R. 2005. "Conductivity Analyzers and Their Application". In Down, R.D; Lehr, J.H. Environmental Instrumentation and Analysis Handbook, by Randy D. Down and Jay H. Lehr Wiley. pp. 491-510.

HYSKO M, 2007. Manuali i mikrobiologjisë. Shtypshkronja, "Julvin 2“, Tiranë.

MARIAT, F 1963: Sur la distribution geographique et la repartition des agents de mycetomes. Bull.Soc, Experimental Pathology, Exot. 56:35-45.

MERCK E, 1982. The testing of water, RFGJ.

MIHO, A. HYSKO, M. DUKA, S. 2010. First Report of Environmental Assessment in Tirana River (Place Bregu Lumit). Constructed Wetland for Nutrient Reductions in the Waters of Tirana River (1 November 2009 - 31 August 2010) http://iep-al.org/docs/TIRANA-RaportJuly-2010.pdf 
M490, 2011, Actinomycete Isolation Agar. Himedia Laboratories. Accessed.at. http://www.himedialabs.com/TD/M490.p $d f$.

PADW, 2010. Protocol of Accepted Drinking Water Testing Methods, Version 2.0, Laboratory Services Branch, Ministry of Environmet, Ontario.

ROBERT A. CORBITT, 1999. Standard Handbook of Environmental Engineering, Second Edition. The McGraw-Hill Companies, Inc.

SCHAAL, K.P. AND H. BICKENBACH. 1978. Soil occurrence of pathogenic nocardiae. Zentralbl. Bakteriol. Suppl. 6: 429-434. 